\title{
Prepartum 2,4-Thiazolidinedione Alters Metabolic Dynamics and Dry Matter Intake of Dairy Cows
}

\author{
K. L. Smith, S. E. Stebulis, ${ }^{1}$ M. R. Waldron, ${ }^{2}$ and T. R. Overton ${ }^{3}$ \\ Department of Animal Science, Cornell University, Ithaca, NY 14853
}

\begin{abstract}
Thiazolidinediones (TZD) are potent, synthetic ligands for peroxisome proliferator activated receptorgamma (PPAR- $\gamma$ ) that reduce plasma nonesterified fatty acids (NEFA) and potentiate the action of insulin in peripheral tissues of several species. Holstein cows $(\mathrm{n}=9)$ entering their second or greater lactation were used to determine whether late prepartum administration of TZD would affect periparturient metabolism and milk production. Cows were limit-fed a total mixed ration (TMR) during the prepartum period to provide no more than $130 \%$ of predicted energy requirements. During the postpartum period cows were fed a common TMR for ad libitum intake. Cows were administered either 2,4-TZD ( $4.0 \mathrm{mg} / \mathrm{kg}$ of body weight) or saline (control) by intrajugular infusion once daily from $25 \mathrm{~d}$ before expected parturition until parturition. Plasma samples were collected daily from $26 \mathrm{~d}$ before expected parturition through $7 \mathrm{~d}$ postpartum. Plasma NEFA concentrations decreased during the prepartum period (d -21 to $-1 ; 70$ vs. $83 \pm 4 \mu \mathrm{Eq} / \mathrm{L})$ and tended to be decreased during the peripartum period $(\mathrm{d}-7$ to $\mathrm{d}+7 ; 113$ vs. $205 \pm 32 \mu \mathrm{Eq} / \mathrm{L}$ ) due to prepartum TZD administration. Plasma concentrations of glucose were not affected by treatment; however, plasma $\beta$-hydroxybutyrate concentrations decreased in TZD-treated cows (8.6 vs. 10.7 $\pm 1.7 \mathrm{mg} / \mathrm{dL}$ ) as parturition approached, and plasma insulin concentrations increased during the peripartum period ( 0.65 vs. $0.38 \pm 0.07 \mathrm{ng} / \mathrm{mL})$. Postpartum liver triglyceride and glycogen content was not affected by treatment. Prepartum TZD administration tended to increase dry matter intake during the peripartum and postpartum periods (16.6 vs. $14.6 \pm 0.8 \mathrm{~kg} / \mathrm{d}$ and 20.0 vs. $17.2 \pm 1.2 \mathrm{~kg} / \mathrm{d}$, respectively). Milk yield for the first $30 \mathrm{~d}$ postpartum and milk composition measured on $\mathrm{d}$
\end{abstract}

Received October 7, 2006.

Accepted April 2, 2007.

${ }^{1}$ Current address: Department of Dairy Science, University of Wisconsin, Madison, WI 53706

${ }^{2}$ Current address: Department of Animal Sciences, University of Vermont, Burlington, VT 05405

${ }^{3}$ Corresponding author: tro2@cornell.edu
8 postpartum were not affected by treatment. There was no effect of prepartum TZD administration on insulin-dependent glucose utilization assessed using insulin challenge during either the prepartum or postpartum periods. These results suggest that administration of TZD during the late prepartum period has the potential to improve metabolic health and DMI of periparturient dairy cows and warrants further investigation.

Key words: transition cow, thiazolidinedione, peroxisome proliferator activated receptor-gamma

\section{INTRODUCTION}

Periparturient dairy cows undergo tremendous adaptations in energy metabolism, particularly in glucose and lipid metabolism, as they transition from late pregnancy to early lactation (Bell, 1995). The homeorhetic coordination required to actualize these metabolic adaptations to support lactation involves a variety of processes and a number of different tissues in the body (Bauman and Elliot, 1983; Bell, 1995). Overall performance and well-being of early lactation cows depends upon the successful coordination of metabolism in support of these adaptations.

One of the key targets for research in transition cow metabolism (Overton and Waldron, 2004) has been aspects of lipid metabolism that relate to mobilization of NEFA from adipose reserves and subsequent metabolism by the liver. Hepatic uptake of NEFA in excess of oxidation or export leads to accumulation of triglycerides in the liver, which increases the risk for development of ketosis and associated disorders (Overton and Waldron, 2004). Few published studies have focused on changes in adipose tissue and the potential to modulate metabolism of adipose tissue to moderate the acute spike in circulating NEFA concentrations that occurs at or after parturition.

One of the primary homeorhetic adaptations during the periparturient period involves the development of insulin resistance during late pregnancy in the form of decreased tissue responses to insulin that continue into early lactation (Smith, 2004). Insulin resistance in peripheral tissues facilitates glucose sparing for the mammary gland (Bauman and Elliot, 1983). Mobilization 
of NEFA from adipose tissue is facilitated by insulin resistance. Recent data from our laboratory (Smith, 2004; Smith et al., 2006) suggest that tissue responses to insulin in dairy cows may be less during the late prepartum period than during the immediate postpartum period.

Recent research suggested that overfeeding dairy cows during the prepartum period may accentuate insulin resistance in adipose tissue, leading to increased NEFA mobilization, lower DMI, and greater risk for lipid-related metabolic disorders (Holtenius et al., 2003). Increased circulating NEFA during the immediate peripartum period likely contributes to the depression in DMI experienced during the immediate peripartum period caused by increased hepatic energy status from oxidation of NEFA (Allen et al., 2005); this scenario likely is exacerbated by increased insulin resistance in adipose tissue caused by overfeeding during the prepartum period.

Most aspects of insulin resistance in adipose tissue are likely mediated through the action of peroxisome proliferator activated receptor-gamma (PPAR- $\gamma$ ). Peroxisome proliferator activated receptor-gamma belongs to a subfamily of the nuclear-receptor family that regulates gene expression in response to ligand binding (Hammarstedt et al., 2005) and is highly expressed in bovine adipose tissue (Sundvold et al., 1997). Activation of PPAR- $\gamma$ potentiates adipocyte differentiation, stimulates insulin action, and decreases the release of free fatty acids from the adipocyte (Houseknecht et al., 2002).

There are many natural ligands for PPAR- $\gamma$ including fatty acids and prostaglandins (Houseknecht et al., 2002); however, the most potent ligands include a family of compounds known as the thiazolidinediones (TZD). When administered to animal models of noninsulin-dependent diabetes mellitus, TZD increased insulin action, decreased plasma free fatty acids, and improved pancreatic $\beta$-cell function. Limited research has been conducted on the activation of PPAR- $\gamma$ and the administration of synthetic PPAR- $\gamma$ ligands, specifically TZD, in ruminants. Kushibiki et al. (2001) determined that administration of TZD to steers injected with tumor necrosis factor- $\alpha$ (TNF- $\alpha$ ) to induce insulin resistance decreased plasma concentrations of NEFA, insulin, and glucagon, suggesting that administration of TZD restored insulin action by reducing circulating NEFA.

We hypothesized that activation of PPAR- $\gamma$ through administration of TZD to dairy cows during the prepartum period would modulate specific aspects of insulin resistance in adipose tissue and decrease circulating concentrations of NEFA during the periparturient period, which may alter the dynamics of DMI during the peripartum period. Therefore, the objectives of this experiment were to determine the metabolic effects during the periparturient period of TZD administration during the late prepartum period.

\section{MATERIALS AND METHODS}

\section{Animals, Treatments, and Sampling}

All procedures involving animals were approved before the onset of the experiment by the Cornell University Institutional Animal Care and Use Committee, and the experiment commenced in September 2005 and ended in January 2006. Holstein cows $(\mathrm{n}=14)$ entering their second or later lactation that had been dried off at $60 \mathrm{~d}$ before expected calving were selected from the Cornell Teaching and Research Center dairy herd and moved to individual tie stalls approximately $32 \mathrm{~d}$ before expected parturition.

Cows were fitted with an indwelling jugular catheter (MicroRenathane Implantation Tubing, $2.03 \mathrm{~mm}$ o.d. $\times$ $1.02 \mathrm{~mm}$ i.d.; Braintree Scientific Inc., Braintree, MA) on d 27 before expected parturition. Beginning on d 25 before expected parturition, cows ( $\mathrm{n}=7$ per treatment) were assigned to 1 of 2 treatments in a completely randomized design and administered either TZD (4.0 mg/ $\mathrm{kg}$ of BW) or saline (control) by intrajugular infusion once daily at $1300 \mathrm{~h}$. Daily administration of treatments continued until parturition. The TZD was obtained as 2,4-thiazolidinedione from Sigma Chemical Co. (St. Louis, MO). Cow assignment to treatments was balanced for BCS and calculated previous 305-d matureequivalent milk yield. Cows were limit-fed a TMR during the prepartum period such that cows would consume no more than $130 \%$ of predicted $\mathrm{NE}_{\mathrm{L}}$ requirements (NRC, 2001). During the postpartum period cows were fed a lactation TMR for ad libitum intake. Individual DMI was recorded from $32 \mathrm{~d}$ before expected parturition through $8 \mathrm{~d}$ postpartum. Ingredient and chemical composition of the diets fed during the experiment are described in Table 1. All nonforage ingredients in both prepartum and postpartum diets were blended by a commercial feed mill into separate concentrate mixtures, and diet mixing at the farm consisted of mixing the component forages with the appropriate concentrate mixture. Fresh feed was provided each morning at $1000 \mathrm{~h}$, orts were weighed and recorded daily, and water was made available at all times. Samples of the forages and concentrate mixtures were obtained weekly throughout the experiment, and DM content determined by drying at $55^{\circ} \mathrm{C}$ until static weight. Amounts of individual feed components in the TMR were adjusted weekly based on changes in the DM content of these feed components. Samples of both the prepartum and postpartum TMR were obtained weekly throughout the 
Table 1. Ingredient and chemical composition (DM basis, \% unless otherwise noted) of prepartum and postpartum diets

\begin{tabular}{|c|c|c|}
\hline Ingredient & Prepartum diet & Postpartum diet \\
\hline Corn silage, processed & 38.1 & 28.7 \\
\hline Alfalfa silage & 14.1 & 15.3 \\
\hline Grass hay & 6.75 & - \\
\hline Alfalfa hay & - & 4.31 \\
\hline Rye straw & 8.52 & 1.12 \\
\hline Ground shelled corn & 1.41 & 19.2 \\
\hline Corn gluten feed & 4.33 & 7.09 \\
\hline Wheat middlings & 6.51 & 6.25 \\
\hline Distillers grains (with solubles) & 0.67 & 4.74 \\
\hline Expeller soybean meal & - & 3.08 \\
\hline Blood meal (flash-dried) & 1.21 & 1.92 \\
\hline Bread meal & 3.35 & 1.89 \\
\hline Mill run & - & 1.57 \\
\hline Tallow (beef) & - & 1.05 \\
\hline Soybean hulls & 4.59 & 0.39 \\
\hline Bio-Chlor ${ }^{1}$ & 4.33 & - \\
\hline Rumen bypass fat ${ }^{2}$ & - & 0.30 \\
\hline Urea & - & 0.26 \\
\hline Cane molasses & 2.28 & 0.09 \\
\hline Limestone & 2.05 & 1.16 \\
\hline Sodium bicarbonate & - & 0.77 \\
\hline Calcium sulfate & 0.67 & 0.15 \\
\hline Yeast culture $^{3}$ & 0.37 & - \\
\hline Magnesium oxide & 0.30 & 0.09 \\
\hline Corn dextrose & 0.20 & - \\
\hline Salt & 0.11 & 0.35 \\
\hline Mepron M85 & - & 0.11 \\
\hline Vitamin A, D, and E premix ${ }^{5}$ & 0.04 & 0.02 \\
\hline Trace mineral premix ${ }^{6}$ & 0.03 & 0.03 \\
\hline Vitamin E premix $^{7}$ & 0.01 & - \\
\hline Rumensin ${ }^{8}$ & 0.01 & 0.01 \\
\hline Sel-Plex- $600^{9}$ & 0.04 & 0.04 \\
\hline Zinc sulfate & 0.01 & 0.01 \\
\hline \multicolumn{3}{|l|}{ Chemical $( \pm \mathrm{SD})^{10}$} \\
\hline $\mathrm{NE}_{\mathrm{L}}{ }^{11} \mathrm{Mcal} / \mathrm{kg}$ & $1.60(0.02)$ & $1.65(0.02)$ \\
\hline $\mathrm{CP}$ & $14.1(0.2)$ & $17.4(1.0)$ \\
\hline Acid detergent insoluble CP & $0.7(0.3)$ & $1.0(0.3)$ \\
\hline Neutral detergent insoluble CP & $1.9(0.1)$ & $2.1(0.1)$ \\
\hline $\mathrm{ADF}$ & $27.3(1.6)$ & $20.8(1.8)$ \\
\hline $\mathrm{NDF}$ & $43.1(2.1)$ & $34.6(2.1)$ \\
\hline Starch & $16.4(0.1)$ & $23.5(1.0)$ \\
\hline $\mathrm{NFC}^{12}$ & 33.3 & 38.6 \\
\hline Ether extract & $3.0(<0.1)$ & $3.7(0.2)$ \\
\hline Ash & $8.4(1.0)$ & $7.8(0.7)$ \\
\hline $\mathrm{Ca}$ & $1.44(0.21)$ & $0.99(0.07)$ \\
\hline $\mathrm{P}$ & $0.40(0.01)$ & $0.46(0.02)$ \\
\hline $\mathrm{K}$ & $1.69(0.19)$ & $1.65(0.22)$ \\
\hline $\mathrm{Mg}$ & $0.28(0.04)$ & $0.25(0.02)$ \\
\hline
\end{tabular}

${ }^{1}$ Anionic supplement; Church and Dwight Animal Nutrition, Princeton, NJ.

${ }^{2}$ Prilled saturated free fatty acids (99\% fatty acid weight basis); Cargill Animal Nutrition proprietary blend, Elk River, MN.

${ }^{3}$ Cargill Animal Nutrition proprietary blend, Elk River, MN.

${ }^{4}$ Rumen-protected methionine (85\% DL-methionine, wt/wt); Degussa Corporation, Kennesaw, GA.

${ }^{5}$ Contained $37,113 \mathrm{IU} / \mathrm{kg}$ of vitamin A, 7,216 IU/kg of vitamin D, and 72,165 IU/ $/ \mathrm{kg}$ of vitamin E.

${ }^{6}$ Contained 112,255 ppm Zn, 19,388 ppm Cu, 91,837 ppm Mn, 2,551 ppm Co, and 1,939 ppm I.

${ }^{7}$ Contained 500,444 IU/kg of vitamin E.

${ }^{8}$ Contained $176 \mathrm{~g} / \mathrm{kg}$ of monensin sodium; Elanco Animal Health, Greenfield, IN.

${ }^{9}$ Selenium yeast; Alltech Inc., Nicholasville, KY.

${ }^{10}$ Based upon 4 composite samples of prepartum TMR and 3 composite samples of postpartum TMR.

${ }^{11}$ Calculated by Dairy One Cooperative (Ithaca, NY) using NRC (2001) equations.

${ }^{12}$ Calculated as $100-[(\mathrm{NDF}-\mathrm{NDFCP})+\mathrm{CP}+$ ash + ether extract $]$; NRC, 2001. 
experiment, and DM content was determined by drying at $55^{\circ} \mathrm{C}$ until static weight. Dry matter contents of these TMR were used in calculation of DMI for the corresponding week. The weekly TMR samples were composited into 4-wk composite samples and submitted $(\mathrm{n}=$ 4 for prepartum TMR and $\mathrm{n}=3$ for postpartum TMR) to a commercial laboratory for wet chemistry analysis (Dairy One Cooperative Inc., Ithaca, NY). Samples were analyzed for DM (method 930.15; AOAC, 2000), CP (method 990.03; AOAC, 2000), ADF and NDF (Van Soest et al., 1991), neutral detergent insoluble CP and acid detergent insoluble CP (Licitra et al., 1996), ether extract (EE; method 2003.05; AOAC, 2000), ash (method 942.05; AOAC, 2000), starch (Application note 319, YSI Inc., Yellow Springs, OH), and macro- and microminerals (Sirois et al., 1994).

Body weights and BCS of each animal were recorded once weekly beginning the week before treatment initiation and continuing throughout the study. Body condition scores were assigned using a 5-point system (Wildman et al., 1982) by 2 individuals and the average of these 2 scores was the assigned value. Daily observations, daily rectal temperatures, and general health records were maintained throughout the study.

After parturition cows were milked twice daily for the first $8 \mathrm{~d}$ postpartum and then switched to 3 times daily milking. Yields were recorded daily for the first $30 \mathrm{~d}$ postpartum and milk was sampled once on $\mathrm{d} 8$ postpartum from both milkings. Samples were composited and stored at $4^{\circ} \mathrm{C}$ with a preservative (Bronopol tablet, D\&F Control System, San Ramon, CA) until analyzed (Dairy One Cooperative Inc.) within $24 \mathrm{~h}$ for fat, protein, lactose using infrared analysis (AOAC, 2000; method 972.160), and SCC by an optical fluorescent method (AOAC, 2000; method 978.26).

\section{Plasma and Tissue Sampling and Analyses}

Blood samples were collected once daily at $1300 \mathrm{~h}$ via the jugular catheter from $\mathrm{d} 26$ before expected parturition to $\mathrm{d} 8$ postpartum. A sterile solution of sodium heparin (200 IU/mL of saline) and Naxcel $(4 \mathrm{mg} / \mathrm{mL}$ of saline, Pfizer Inc., New York, NY) was injected into the catheter after sampling to prevent blood coagulation and bacterial growth. In addition, insulin challenges $(0.8$ and $2.4 \mu \mathrm{g} / \mathrm{kg}$ of BW) were conducted on each cow at $1400 \mathrm{~h}$ on $\mathrm{d}-10$ and -9 relative to expected parturition, and $d 6$ and 7 postpartum. The order of challenge dose was randomized within prepartum and postpartum periods to minimize any potential confounding effects of day of challenge relative to parturition. Blood was sampled at $-30,-20,-10,0,2.5,5,7.5,10,12.5$, $15,17.5,20,25,30,45,60,90,120$, and 130 min relative to the insulin injection. Blood samples collected both on a daily basis and during the insulin challenges were transferred into glass test tubes containing sodium hep$\operatorname{arin}(100 \mathrm{IU} / \mathrm{mL}$ of blood). Plasma was harvested following centrifugation $\left(2,800 \times g\right.$ for $15 \mathrm{~min}$ at $\left.4^{\circ} \mathrm{C}\right)$, snapfrozen in liquid $\mathrm{N}_{2}$, and stored at $-20^{\circ} \mathrm{C}$ until analyzed for metabolites. Plasma concentrations of glucose were determined by enzymatic analysis (glucose oxidase) using a commercial kit (kit 510-A, Sigma Chemical). Intra- and interassay coefficients of variation $(\mathbf{C V})$ for the glucose assay were 2.6 and $2.7 \%$, respectively. Plasma concentrations of NEFA were analyzed by enzymatic analysis (NEFA-C kit, WAKO Pure Chemical Industries, Osaka, Japan) using modifications described by McCutcheon and Bauman (1986). Intra- and interassay CV for the NEFA assay were 3.1 and $3.4 \%$, respectively. Plasma concentrations of BHBA for samples collected during the covariate period and on $\mathrm{d}-21,-17,-14,-10$, $-7,-3$, and on d 0 through 7 relative to parturition were determined by enzymatic analysis (BHBA dehydrogenase kit \#310, Sigma Chemical). Intra- and interassay CV for the BHBA assay were 3.4\%. All spectrophotometric measurements were conducted using a Versa $a_{\max }$ tunable microplate reader (Molecular Devices, Sunnyvale, CA). In addition, plasma was analyzed for concentrations of insulin by RIA (Ehrhardt et al., 2001) using bovine insulin (Elanco Animal Health, Greenfield, IN) for iodination and standards (the lowest standard was $0.05 \mathrm{ng} / \mathrm{mL}$ ). Intra- and interassay $\mathrm{CV}$ for the insulin RIA were 10.8 and $11.1 \%$, respectively.

Liver samples were obtained from each cow via percutaneous trochar biopsy on d 8 postpartum. Briefly, the biopsy site at the 11th intercostal space was clipped and scrubbed using surgical scrub [Betadine Surgical Scrub (7.5\% povidone-iodine), Purdue Frederick, Stamford, CT]. A local anesthetic (Lidocaine $\mathrm{HCl}, 2 \%$, Butler Animal Health, Dublin, OH) was administered percutaneously; an incision $(\sim 3 \mathrm{~cm})$ was made percutaneously, and the liver was biopsied using a stainless steel biopsy tool (30 $\mathrm{cm}$ long by $1 \mathrm{~cm}$ o.d.). Following biopsy, the incision was closed using surgical staples (3M Precise Vista Disposable Skin Stapler, 3M, St. Paul, MN) and a topical antiseptic applied (BluKote aerosol spray, H. W. Naylor Co., Morris, NY). Liver was blotted to remove excess blood and connective tissue, snap frozen in liquid $\mathrm{N} 2$, and stored at $-80^{\circ} \mathrm{C}$ until analyzed for triglyceride (TG) and glycogen content.

Glycogen content of liver was determined according to the procedures described in Hawk and Bergeim (1926) with modifications described by Bernal-Santos et al. (2003). Liver TG content was determined using the Folch extraction method (Folch et al., 1957) followed by a colorimetric method based upon the Hantzsch condensation for estimating serum TG (Fletcher, 1968) 
with modifications described by Foster and Dunn (1973).

\section{Calculations for Insulin Challenges}

Following insulin challenges, the overall response patterns of insulin and glucose were similar for both doses of insulin and at both timepoints relative to parturition (data not shown). The nadir for plasma concentrations of glucose occurred by 45 min following insulin administration and returned to baseline by $120 \mathrm{~min}$. To minimize the contribution of clearance and counterregulatory effects, the response area for glucose was calculated from the time of challenge to $25 \mathrm{~min}$ postchallenge and the response area for insulin was calculated from the time of challenge to $30 \mathrm{~min}$ postchallenge (Sechen et al., 1989; Smith et al., 2006). Response areas were based upon changes in postchallenge concentrations compared with baseline concentrations (mean of concentrations at $-30,-20,-10$, and 0 min from the time of the challenge injection for glucose and mean of concentrations at $-30,-20$, and $-10 \mathrm{~min}$ from the time of the challenge injection for insulin; Sechen et al., 1989). The doses selected ( 0.8 and $2.4 \mu \mathrm{g}$ of insulin $/ \mathrm{kg}$ of BW) were used as proxies for tissue sensitivity and responsiveness, respectively (Smith et al., 2006). Metabolite and hormone responses to each challenge were calculated as area under the response curve using cubic spline interpolation and the trapezoidal rule with the EXPAND procedure in SAS (SAS Institute, 2001).

\section{Statistical Analyses}

Prior to statistical analysis, 5 cows were removed from the data set. Two cows (1 was determined not pregnant after assignment to treatment and 1 experienced a retained placenta) were removed from the control group and 3 cows ( 1 cow experienced a uterine torsion, 1 cow pinched a nerve at parturition and was recumbent during much of the postpartum period, and 1 cow experienced a retained placenta) were removed from the TZD group.

Pretreatment values for plasma variables and DMI, $\mathrm{BW}$, and BCS measured or assessed during the week before assignment to treatments were used as covariates during analysis of covariance applied to their corresponding measurements during the treatment period. The ANOVA was conducted on measurements conducted over time (plasma variables, DMI, BW, BCS, and milk yield) using the MIXED procedure (SAS Institute, 2001) for a completely randomized design with repeated measures. The model included fixed effects of covariate, treatment, time, and the interaction of treatment and time. The random effect was cow nested within treatment. For each variable, cow was subjected to 6 covariance structures (first-order autoregressive, heterogeneous first-order autoregressive, compound symmetry, heterogeneous compound symmetry, firstorder antedependence, and unstructured). The structure yielding the smallest Akaike's information criterion was selected; in almost all cases this was the heterogeneous first-order autoregressive structure. The method of Kenward-Rogers was used for calculation of denominator degrees of freedom. Covariates were dropped from the model if $P>0.10$ and the data reanalyzed. Prepartum (d -21 to -1$)$, postpartum (d 0 to +7 ), and peripartum ( $\mathrm{d}-7$ to +7$)$ data were analyzed separately except for BW and BCS, for which prepartum and postpartum values were analyzed together. Measurements that were not repeated over time (e.g., milk composition, calf birth weight, liver composition, postpartum net energy balance) were subjected to ANOVA using the MIXED procedure of SAS. The model included the effects of treatment. Insulin challenge data were analyzed separately during the prepartum and postpartum periods using the MIXED procedure of SAS. Terms in the model included the effects of treatment, dose, and the interaction of treatment and dose.

Statistical significance was declared at $P<0.05$ and trends were discussed at $0.05<P<0.10$. Least squares means and SEM are reported throughout. For measurements repeated over time, mean separation for treatment means by day was conducted using the PDIFF option in SAS when treatment by day interactions had a $P$-value $<0.10$.

\section{RESULTS}

Overall plasma concentrations of plasma NEFA, BHBA, glucose, and insulin and liver concentrations of TG and glycogen during the prepartum ( $d-21$ to -1 relative to parturition), postpartum (d 0 to 7 postpartum), and peripartum ( $\mathrm{d}-7$ to +7 relative to parturition) periods are presented in Table 2 . Plasma NEFA concentrations (Table 2$)$ decreased $(P=0.05)$ during the prepartum period and tended $(P=0.06)$ to decrease during the peripartum period for cows administered TZD during the prepartum period, but effects of prepartum TZD administration on postpartum plasma NEFA concentrations were not significant $(P=0.16)$ when postpartum data were considered independently of prepartum data. Overall plasma BHBA concentrations (Table 2) were not affected by treatment during either the prepartum $(P=0.44)$, postpartum $(P=0.20)$, or peripartum $(P=0.39)$ periods; however, an interaction existed $(P=$ 0.02 ) for treatment and day during the prepartum period such that circulating concentrations of BHBA were similar between treatments at $21 \mathrm{~d}$ before parturition 
Table 2. Least squares means for the effects of prepartum thiazolidinedione (TZD) treatment on plasma metabolites, plasma insulin, and liver composition

\begin{tabular}{|c|c|c|c|c|c|}
\hline \multirow[b]{2}{*}{ Item } & \multicolumn{2}{|c|}{ Prepartum treatment $(\mathrm{Trt})^{1}$} & \multirow[b]{2}{*}{ SEM } & \multicolumn{2}{|c|}{$P$-value } \\
\hline & Saline & TZD & & Trt & Trt $\times$ day \\
\hline \multicolumn{6}{|l|}{ NEFA, $\mu \mathrm{Eq} / \mathrm{L}$} \\
\hline Prepartum $^{2}$ & 83 & 70 & 4 & 0.05 & 0.58 \\
\hline Postpartum $^{3}$ & 285 & 143 & 67 & 0.16 & 0.33 \\
\hline Peripartum $^{4}$ & 205 & 113 & 32 & 0.06 & 0.76 \\
\hline \multicolumn{6}{|l|}{ BHBA, mg/dL } \\
\hline Prepartum $^{5}$ & 10.7 & 8.6 & 1.7 & 0.44 & 0.02 \\
\hline Postpartum ${ }^{3}$ & 8.8 & 7.6 & 0.7 & 0.20 & 0.75 \\
\hline Peripartum $^{6}$ & 8.7 & 7.9 & 0.7 & 0.39 & 0.52 \\
\hline \multicolumn{6}{|l|}{ Glucose, mg/dL } \\
\hline Prepartum $^{2}$ & 61.0 & 58.9 & 1.1 & 0.18 & 0.34 \\
\hline Postpartum $^{3}$ & 51.0 & 51.8 & 3.7 & 0.87 & 0.81 \\
\hline Peripartum $^{4}$ & 55.1 & 55.7 & 2.6 & 0.86 & 0.44 \\
\hline \multicolumn{6}{|l|}{ Insulin, ng/mL } \\
\hline Prepartum $^{2}$ & 1.12 & 1.54 & 0.23 & 0.22 & 0.86 \\
\hline Postpartum $^{3}$ & 0.25 & 0.34 & 0.06 & 0.32 & 0.10 \\
\hline Peripartum $^{4}$ & 0.38 & 0.65 & 0.07 & 0.02 & 0.34 \\
\hline \multicolumn{6}{|l|}{ Liver composition $^{7}$} \\
\hline Triglyceride, \% wet weight & 17.1 & 11.8 & 3.5 & 0.30 & - \\
\hline Glycogen, $\%$ wet weight & 2.53 & 2.38 & 0.36 & 0.77 & - \\
\hline Triglyceride:glycogen & 7.8 & 5.8 & 2.6 & 0.58 & - \\
\hline
\end{tabular}

${ }^{1}$ Cows received a prepartum treatment of TZD $(n=4$ cows $)$ or saline $(n=5$ cows $)$ from 25 d before expected parturition through parturition.

${ }^{2}$ Represents data collected daily from $21 \mathrm{~d}$ through $1 \mathrm{~d}$ before parturition.

${ }^{3}$ Represents data collected daily from parturition through $7 \mathrm{~d}$ postpartum.

${ }^{4}$ Represents data collected daily from $7 \mathrm{~d}$ before parturition through $7 \mathrm{~d}$ postpartum.

${ }^{5}$ Represents data collected every $3 \mathrm{~d}$ from $21 \mathrm{~d}$ through $1 \mathrm{~d}$ before parturition.

${ }^{6}$ Represents data collected every $3 \mathrm{~d}$ from $7 \mathrm{~d}$ through $1 \mathrm{~d}$ before parturition and daily from parturition through $7 \mathrm{~d}$ postpartum.

${ }^{7}$ Represents data collected on d 8 postpartum.

and decreased in cows administered TZD compared with controls as parturition approached (Figure 1). Concentrations of glucose in plasma (Table 2) were not affected during the prepartum $(P=0.18)$, postpartum $(P=0.87)$, or peripartum $(P=0.86)$ periods. Overall plasma insulin concentrations were not affected by treatment during the prepartum $(P=0.22)$ or postpartum periods $(P=0.32)$; however, cows administered TZD had increased $(P=0.02)$ plasma concentrations of insulin during the peripartum period. A trend $(P=0.10)$ existed for an interaction of treatment and time during the postpartum period (Figure 2).

Liver composition from samples collected via biopsy on $\mathrm{d} 8$ postpartum is described in Table 2. Concentrations of TG $(P=0.30)$, glycogen $(P=0.77)$, and the ratio of TG to glycogen in liver $(P=0.58)$ were not affected by treatment.

Overall effects of prepartum TZD administration on DMI, milk yield, milk composition, calculated net energy balance, BCS, BW, and calf birth weight are described in Table 3. Administration of TZD during the prepartum period did not affect prepartum DMI $(P=$ 0.48); however, it tended to increase DMI during both

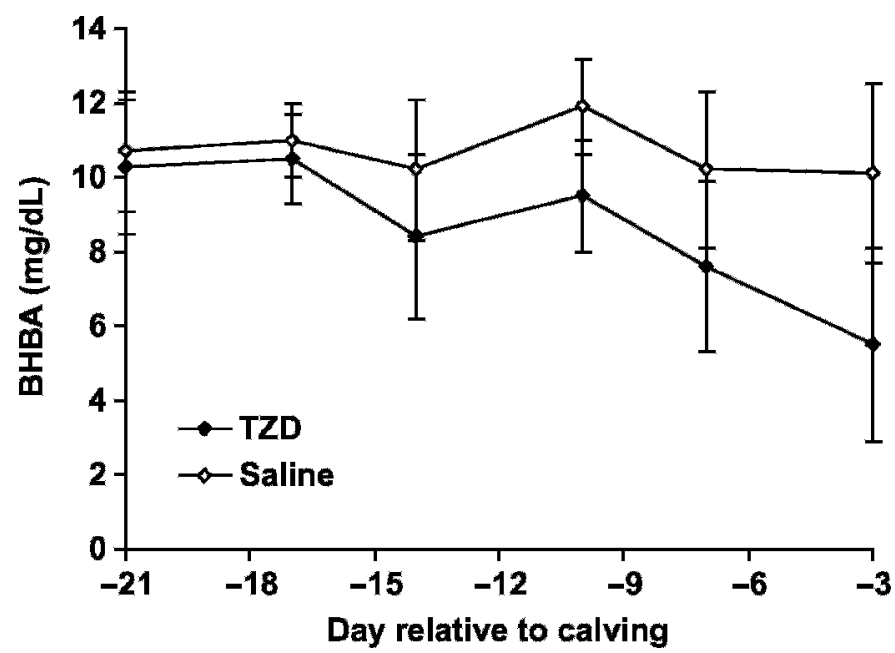

Figure 1. Concentrations of plasma BHBA during the prepartum period for cows administered thiazolidinedione (TZD) or saline during the prepartum period. Data were collected every $3 \mathrm{~d}$ from $21 \mathrm{~d}$ through $1 \mathrm{~d}$ before parturition. Values are least squares means with SEM; $\mathrm{n}=4$ for TZD and $\mathrm{n}=5$ for saline; the $P$-value for the interaction of treatment and day was 0.02 . 


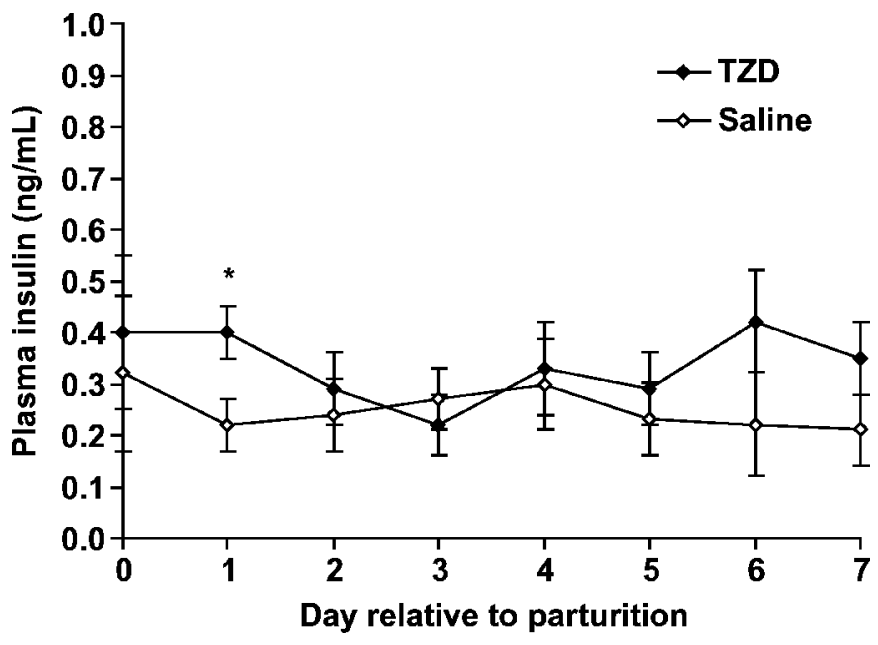

Figure 2. Postpartum concentrations of plasma insulin for cows administered thiazolidinedione (TZD) or saline during the prepartum period. Data were collected daily from parturition through $7 \mathrm{~d}$ postpartum. Values are least squares means with SEM; $n=4$ for TZD and $\mathrm{n}=5$ for saline; the $P$-value for the interaction of treatment and day was 0.10 . Differences at individual times are indicated by $*(P$ $<0.05)$.

the peripartum $(P=0.08)$ and postpartum $(P=0.10)$ periods (Table 3 ).

Administration of TZD during the prepartum period did not affect milk yield either for the first $7 \mathrm{~d}$ postpartum $(P=0.83)$ or the first $30 \mathrm{~d}$ postpartum $(P=0.25$; Table 3 ), and cows assigned to this experiment averaged $52.5 \mathrm{~kg} / \mathrm{d}$ of milk by $30 \mathrm{~d}$ postpartum (Figure 3). Milk composition measured on d 8 postpartum was not affected by treatment $(P>0.31$; Table 3$)$. Saline-treated cows tended $(P=0.09)$ to have higher BCS (Table 3) than TZD-treated cows; however, treatment by time effects were not significant $(P=0.83)$, suggesting that there was no effect of prepartum treatment on BCS dynamics through the prepartum period and wk 1 postpartum. Effects of treatment and interactions of treatment and time on BW were not significant $(P=0.61$; Table 3$)$. Finally, there was no effect $(P=0.58)$ of prepartum treatment on calf birth weight (Table 3 ).

Responses to insulin challenges conducted during the prepartum and postpartum periods are depicted in Figures 4 and 5. Following insulin challenge, plasma concentrations of glucose started to decrease immediately following time zero, reached nadir by 45 min postinjection in all groups at all doses, and returned to baseline by 120 min postinjection (data not shown). Prepartum treatment with TZD did not affect the overall responses of glucose or insulin area under the curve (AUC) to insulin challenge during either the prepartum $(P=0.82$; Figure 4$)$ or postpartum $(P=0.64$; Figure 5$)$ periods, and the interaction of treatment and dose was not sig- nificant during either the prepartum $(P=0.87)$ or postpartum $(P=0.16)$ periods.

\section{DISCUSSION}

Insulin resistance in late pregnancy is an important adaptation that develops in both skeletal muscle and adipose tissue and continues into early lactation to spare glucose for the gravid uterus and mammary gland (Bauman and Elliot, 1983; Bell, 1995). However, insulin resistance prepartum likely contributes to the concurrent acute increase in circulating NEFA and decrease in DMI that occurs during the late prepartum period (Smith, 2004; Allen et al., 2005). This relationship is associated with all periparturient health disorders with etiologies based on energy metabolism, immune function, or both (displaced abomasum, ketosis, fatty liver, retained placenta, metritis, and mastitis).

We expect that most aspects of insulin resistance in adipose tissue in dairy cows are mediated through the action of PPAR- $\gamma$ during the transition period and expect that TZD administration would directly activate PPAR- $\gamma$ in adipose tissue. Only one other study has been published in which TZD were administered to ruminants (Kushibiki et al., 2001). This is the first experiment in which TZD was administered to dairy cows during the periparturient period.

In this experiment, plasma NEFA concentrations in control cows during the immediate peripartum period and first $7 \mathrm{~d}$ postpartum were lower than those typically reported (Rabelo et al., 2005). This was probably the result of 2 factors. First, control cows in this experiment consumed more DM $(\sim 3 \mathrm{~kg})$ than typically reported (see above citation) during the first week of lactation, perhaps related to the lack of decrease in DMI as cows approached parturition (Grummer et al., 2004). Second, blood was sampled from these cows $\sim 3 \mathrm{~h}$ postfeeding, whereas it was sampled at or before the time of feeding in the other experiments. In a preliminary experiment (data not shown), a separate set of cows fed the same postpartum ration had markedly lower plasma NEFA concentrations at $3 \mathrm{~h}$ postfeeding compared with immediately prefeeding ( 240 vs. $720 \mu \mathrm{Eq} / \mathrm{L})$. Despite the comparatively low plasma concentrations of NEFA in control cows, prepartum administration of TZD decreased plasma NEFA concentrations during the prepartum period and tended to decrease plasma NEFA concentrations from $7 \mathrm{~d}$ before parturition to $7 \mathrm{~d}$ postpartum. Kushibiki et al. (2001) administered TNF- $\alpha$ to steers for $9 \mathrm{~d}$ to induce insulin resistance and increase plasma NEFA. In their experiment, administration of $2.0 \mathrm{mg}$ of TZD/kg of BW to animals treated with TNF$\alpha$ significantly reduced plasma NEFA after $d 2$ of treatment. In addition, the authors reported that TZD- 
Table 3. Least squares means for the effects of prepartum thiazolidinedione (TZD) treatment on production variables

\begin{tabular}{|c|c|c|c|c|c|}
\hline \multirow[b]{2}{*}{ Item } & \multicolumn{2}{|c|}{$\begin{array}{l}\text { Prepartum treatment } \\
(\text { (Trt })^{1}\end{array}$} & \multirow[b]{2}{*}{ SEM } & \multicolumn{2}{|c|}{$P$-value } \\
\hline & Saline & TZD & & Trt & Trt $\times$ time \\
\hline \multicolumn{6}{|l|}{$\mathrm{DMI}, \mathrm{kg} / \mathrm{d}$} \\
\hline Prepartum $^{2}$ & 12.5 & 12.7 & 0.2 & 0.48 & 0.57 \\
\hline Postpartum $^{3}$ & 17.2 & 20.0 & 1.2 & 0.10 & 0.96 \\
\hline Peripartum $^{4}$ & 14.6 & 16.6 & 0.8 & 0.08 & 0.39 \\
\hline \multicolumn{6}{|l|}{ Milk yield, $\mathrm{kg} / \mathrm{d}$} \\
\hline d 0 through 7 & 28.3 & 28.8 & 1.7 & 0.83 & 0.25 \\
\hline d 0 through 30 & 44.2 & 42.5 & 1.1 & 0.25 & 0.55 \\
\hline \multicolumn{6}{|l|}{ Milk components ${ }^{5}$} \\
\hline Fat, \% & 5.26 & 4.82 & 0.29 & 0.31 & - \\
\hline True protein, $\%$ & 3.21 & 3.30 & 0.16 & 0.68 & - \\
\hline Lactose, \% & 4.50 & 4.50 & 0.09 & 0.99 & - \\
\hline Total solids, \% & 14.0 & 13.6 & 0.4 & 0.45 & - \\
\hline $\mathrm{SCC}, \times 1,000$ & 115 & 237 & 97 & 0.38 & - \\
\hline MUN, mg/dL & 13.6 & 13.3 & 0.7 & 0.79 & - \\
\hline \multicolumn{6}{|l|}{ Net energy balance ${ }^{6}$} \\
\hline Prepartum, Mcal/d & 3.7 & 4.1 & 0.2 & 0.25 & 0.78 \\
\hline Prepartum, \% & 126 & 126 & 2.0 & 0.85 & 0.74 \\
\hline Postpartum, Mcal/d & -6.4 & -3.9 & 2.5 & 0.48 & - \\
\hline Postpartum, \% & 84 & 91 & 6 & 0.41 & - \\
\hline $\mathrm{BCS}^{7^{7}}$ & 3.24 & 3.04 & 0.08 & 0.09 & 0.83 \\
\hline BW, kg & 711 & 706 & 16 & 0.83 & 0.61 \\
\hline Calf birth weight, ${ }^{8} \mathrm{~kg}$ & 45.8 & 44.2 & 1.9 & 0.58 & - \\
\hline
\end{tabular}

${ }^{1}$ Cows received a prepartum treatment of TZD $(n=4$ cows) or saline $(n=5$ cows $)$ from 25 d before expected parturition through parturition.

${ }^{2}$ Represents data collected daily from $21 \mathrm{~d}$ through $1 \mathrm{~d}$ before parturition.

${ }^{3}$ Represents data collected daily from parturition through $7 \mathrm{~d}$ postpartum.

${ }^{4}$ Represents data collected daily from $7 \mathrm{~d}$ before parturition through $7 \mathrm{~d}$ postpartum.

${ }^{5}$ Components measured on d 8 postpartum only.

${ }^{6}$ Calculated according to NRC (2001). Postpartum energy balance was calculated for using DMI and milk yield from $\mathrm{d} 7$ postpartum and the milk component data collected on $\mathrm{d} 8$.

${ }^{7}$ Five-point scale (Wildman et al., 1982).

${ }^{8}$ TZD-treated cows had 2 heifers and 2 males from 4 cows; saline cows had 4 heifers and 2 males from 5 cows ( 1 set of twins). Average days over/under due date $=-0.22$. All calves were born alive. The one set of twins was removed from the data set prior to analysis.

treated animals had significantly lower plasma insulin concentrations than those given only TNF- $\alpha$. In our experiment, prepartum TZD administration increased circulating concentrations of insulin during the peripartum period. Specific reasons for the increase in circulating insulin during the immediate peripartum period in this experiment, beyond the potential for some influence of the trend for increased peripartum DMI in TZDtreated cows, is not known. However, Houseknecht et al. (2002) reported that pancreatic $\beta$-cell function was improved by TZD administration to animal models for noninsulin-dependent diabetes mellitus. Kushibiki et al. (2001) reported that TZD administration improved insulin-dependent glucose utilization; such effects likely would decrease circulating insulin concentrations rather than the reverse as measured in our experiment. These results suggest that periparturient insulin resistance likely differs from insulin resistance induced by TNF- $\alpha$.
Plasma concentrations of BHBA were decreased in TZD-treated cows as parturition approached in this experiment (Figure 1). It is uncertain whether this was a downstream effect of the decreased circulating NEFA in TZD-treated cows during the prepartum period or a direct effect on either overall hepatic fatty acid oxidation or partitioning within hepatic fatty oxidation between complete oxidation or ketogenesis. Ide et al. (2000) reported that administration of TZD specific to PPAR- $\gamma$ did not affect fatty acid oxidation in liver of Zucker diabetic rats; however, administration of a dual agonist for both PPAR- $\alpha$ and PPAR- $\gamma$ increased hepatic capacity to oxidize palmitic and stearic acids. Drackley and Andersen (2006) suggested that dietary or pharmacologic manipulation of PPAR- $\alpha$ in liver of dairy cows would increase $\beta$-oxidation of fatty acids in liver. Given that increased hepatic $\beta$-oxidation likely would coincidentally increase circulating BHBA, the decreased concentrations of BHBA in TZD-treated cows suggest that 


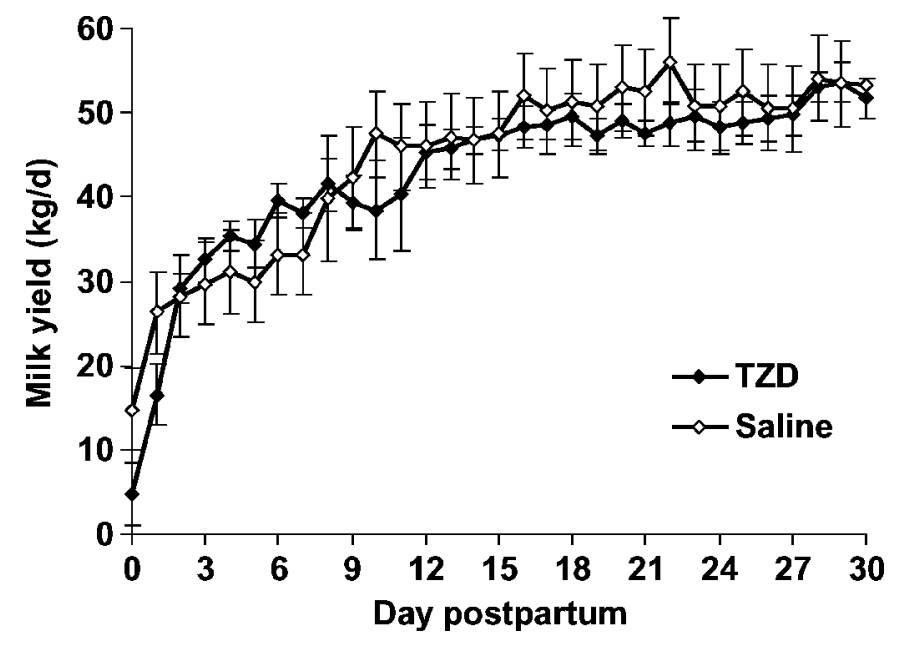

Figure 3. Pattern of milk yield during the first $30 \mathrm{~d}$ postpartum for cows administered thiazolidinedione (TZD) or saline. Values are least squares means with SEM; $\mathrm{n}=4$ for TZD and $\mathrm{n}=5$ for saline; the $P$-value for the effect of treatment was 0.25 and the $P$-value for the interaction of treatment and day was 0.55.

any effect of TZD administration on hepatic fatty acid metabolism was indirect.

Despite the large decrease in plasma NEFA concentrations during the periparturient period for cows treated with TZD during the prepartum period, differences in liver TG content measured in samples collected on d 8 postpartum were not significant. Although we recognized that the limited power of the current experiment likely would not enable us to determine statistically significant differences in liver TG content, we collected the samples to determine whether the patterns of response were consistent with other results and to help target subsequent research.

Cows that were treated during the prepartum period with TZD tended to have higher DMI compared with controls (Table 3 ). This could be attributed to the reduction in plasma NEFA just before and at the time of calving leading to decreased hepatic oxidation of NEFA (Allen et al., 2005); however, there could have been a direct effect or a carryover effect of prepartum TZD administration on postpartum DMI. Activation of PPAR- $\gamma$ by TZD administration has been shown to increase food intake in rats (Larsen et al., 2003).

Milk yield during the first $30 \mathrm{~d}$ postpartum and milk composition assessed on $d 8$ postpartum were not affected by prepartum TZD administration in this experiment. The objective of this experiment was to examine the effects of TZD administration on metabolism, with recognition that effects on milk production and composition would require larger-scale experimentation for adequate study. We measured milk yield primarily to determine whether prepartum TZD administration would

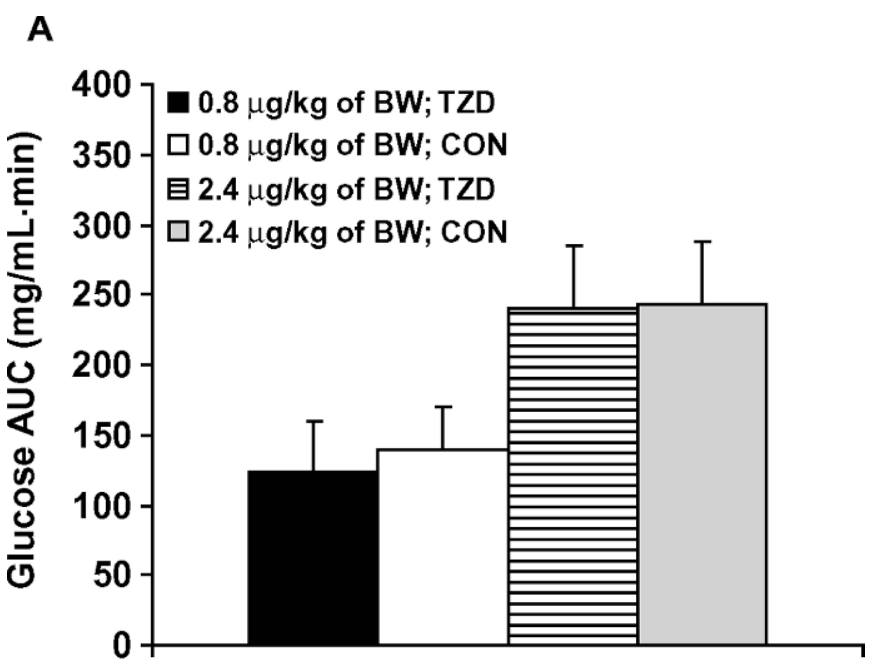

B

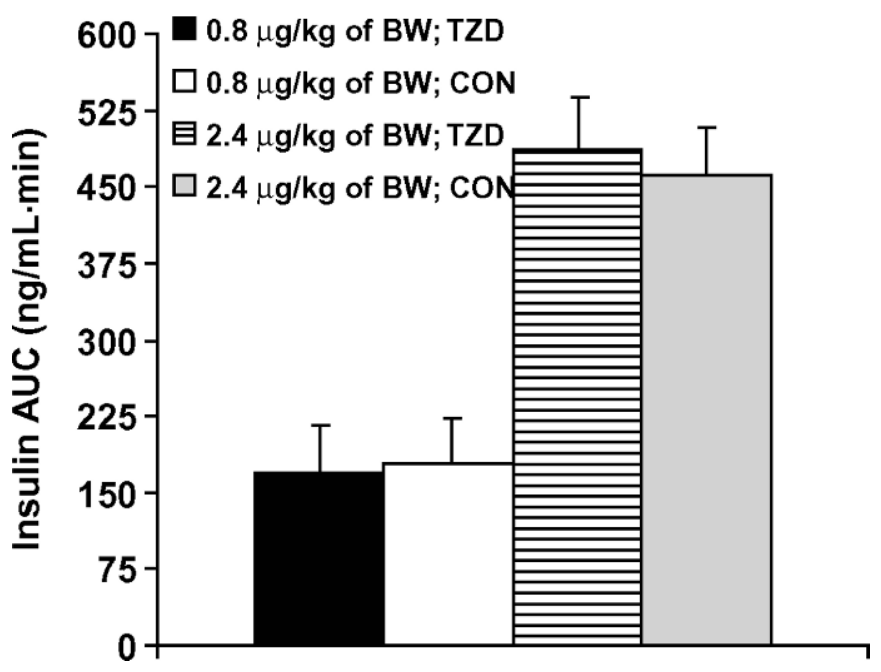

Figure 4. Prepartum responses to insulin challenge with 0.8 or $2.4 \mu \mathrm{g}$ of insulin/kg of $\mathrm{BW}$ on $\mathrm{d}-10$ or $\mathrm{d}-9$ relative to expected parturition. Values are least squares means for area under the curve (AUC) with SEM; $\mathrm{n}=4$ for thiazolidinedione (TZD) and $\mathrm{n}=5$ for saline (CON). A) Responses of plasma glucose; the $P$-values for the effects of treatment, dose, and the interaction of treatment and dose were $0.82,0.01$, and 0.87 , respectively. B) Responses of plasma insulin; the $P$-values for the effects of treatment, dose, and the interaction of treatment and dose were $0.90,0.0001$, and 0.87 , respectively.

cause any pronounced changes in milk yield during the early postpartum period.

Sevillano et al. (2005) reported that newborn rats from mothers treated with TZD had a lower body mass than controls, but the size of the litter was not changed. In our study there was no difference in calf birth weight between TZD-treated cows and controls, perhaps because of the relatively short duration of TZD administration or other uncharacterized species differences.

Administration of TZD prepartum did not affect responses of glucose and insulin to challenge with either 
A

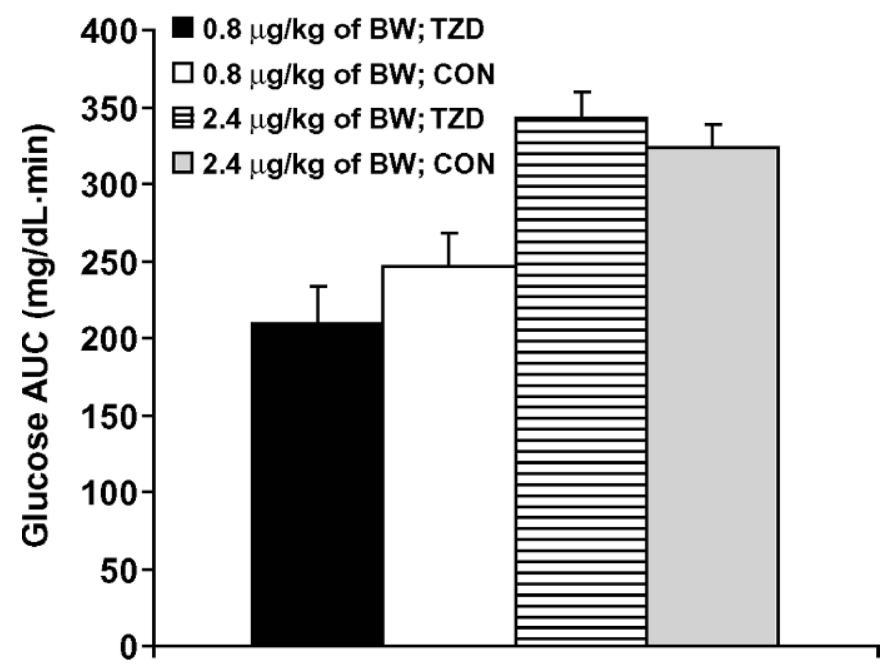

B

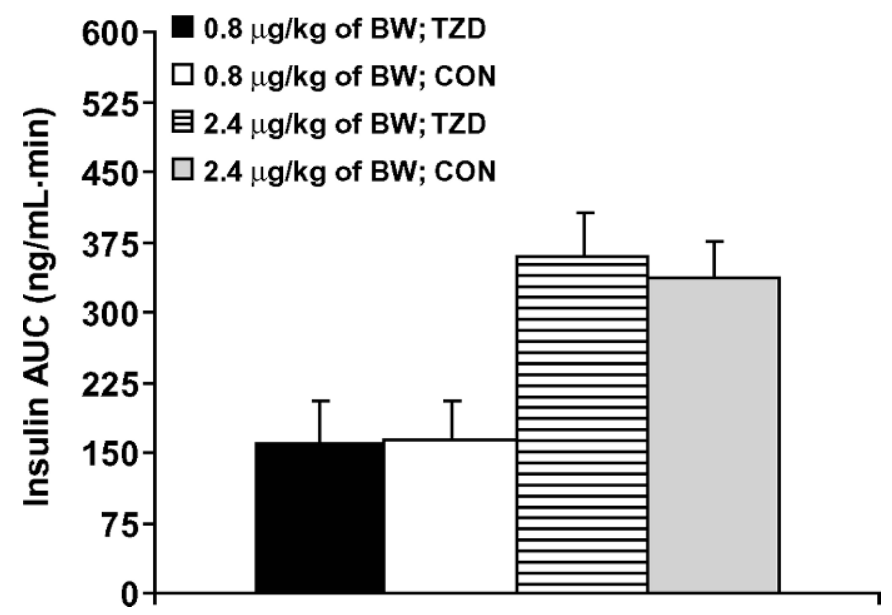

Figure 5. Postpartum responses to insulin challenge with 0.8 or $2.4 \mu \mathrm{g}$ of insulin/kg of BW on d 6 or 7 postpartum. Values are least squares means for area under the curve (AUC) with SEM; $n=4$ for thiazolidinedione (TZD) and $\mathrm{n}=5$ for saline (CON). A) Responses of plasma glucose; the $P$-values for the effects of treatment, dose, and the interaction of treatment and dose were $0.64,0.0001$, and 0.16 , respectively. B) Responses of plasma insulin; the $P$-values for the effects of treatment, dose, and the interaction of treatment and dose were $0.82,0.0007$, and 0.75 , respectively.

0.8 or $2.4 \mu \mathrm{g}$ of insulin/kg of BW during either the prepartum or postpartum periods. These results indicate that prepartum TZD treatment did not affect insulin-dependent glucose utilization in this experiment. In the only study published in ruminants using TZD, Kushibiki et al. (2001) reported that TZD-treated steers had a larger glucose AUC in response to insulin challenge. The authors did not report insulin AUC, so it is not possible to compare insulin responses to insulin challenge to confirm if TZD treatment reduced resis- tance to insulin in their experiment. In addition, the authors did not make a comparison between multiple doses of insulin and therefore we cannot make conclusions about insulin sensitivity, only general conclusions about insulin response. Nevertheless, they concluded that TZD administration partially reversed the experimentally induced insulin resistance.

The results of our insulin challenges suggest that TZD administered to cows in our experiment did not appear to increase insulin-dependent glucose utilization by muscle; hence, TZD administration did not appear to compromise the important adaptations in glucose metabolism that must occur in late pregnancy and early lactation (Bauman and Elliot, 1983; Bell, 1995). This result is expected, because PPAR- $\gamma$ expression is low in skeletal muscle (Sundvold et al., 1997), the predominant target for insulin-dependent glucose utilization. Despite the fact that PPAR- $\gamma$, the main target of action of TZD, is expressed mostly in adipose tissue, TZD can exert some action on glucose disposal in skeletal muscle in some species; however, the basis for these actions has not been thoroughly described.

\section{CONCLUSIONS}

Administration of TZD during the late prepartum period in this experiment appeared to alter the dynamics of plasma NEFA concentrations and DMI during the periparturient period, and has the potential to improve the metabolic health of periparturient dairy cows. Further research should be conducted to confirm these results, enhance our mechanistic understanding of the effects of prepartum TZD administration on periparturient metabolism, and extend these results to determine whether TZD administration indeed can decrease incidence of metabolic disorders in periparturient dairy cows.

\section{ACKNOWLEDGMENTS}

The assistance of the following students and colleagues at Cornell University in implementing the study is gratefully acknowledged and appreciated: J. W. Perfield II, S. Tucker, R. Ehrhardt, D. Dwyer, B. Thering, J. M. Ramos-Nieves, and the staff at the Cornell University Dairy Teaching and Research Center.

\section{REFERENCES}

AOAC. 2000. Official Methods of Analysis. 17th ed. Association of Official Analytical Chemists, Arlington, VA.

Allen, M. S., B. J. Bradford, and K. J. Harvatine. 2005. The cow as a model to study food intake regulation. Annu. Rev. Nutr. 25:523-547.

Bauman, D. E., and J. M. Elliot. 1983. Control of nutrient partitioning in lactating ruminants. Pages 437-468 in Biochemistry of Lacta- 
tion. T. B. Mepham, ed. Elsevier Science Publishers, Amsterdam, the Netherlands.

Bell, A. W. 1995. Regulation of organic nutrient metabolism during transition from late pregnancy to early lactation. J. Anim. Sci. 73:2804-2819.

Bernal-Santos, G., J. W. Perfield II, D. M. Barbano, D. E. Bauman, and T. R. Overton. 2003. Production responses of dairy cows to dietary supplementation with conjugated linoleic acid (CLA) during the transition period and early lactation. J. Dairy Sci. 86:3218-3228.

Drackley, J. K., and J. B. Andersen. 2006. Splanchic metabolism of long-chain fatty acids in ruminants. Pages 199-224 in Ruminant physiology: Digestion, metabolism, and impact of nutrition on gene expression, immunology, and stress. K. Sejrsen, T. Hvelplund, and M. O. Nielsen, ed. Wageningen Academic Publishers, Wageningen, the Netherlands.

Ehrhardt, R. A., R. M. Slepetis, A. W. Bell, and Y. R. Boisclair. 2001. Maternal leptin is elevated during pregnancy in sheep. Domest. Anim. Endocrinol. 21:85-96.

Fletcher, M. J. 1968. A colorimetric method for estimating serum triglycerides. Clin. Chim. Acta 22:393-397.

Folch, J. M., M. Lees, and G. H. Sloane Stanley. 1957. A simple method for the isolation and purification of total lipids from animal tissue. J. Biol. Chem. 226:497-509.

Foster, L. B., and R. T. Dunn. 1973. Stable reagents for determination of serum triglycerides by a colorimetric Hantzsch condensation metod. Clin. Chem. 19:338-340.

Grummer, R. R., D. G. Mashek, and A. Hayirli. 2004. Dry matter intake and energy balance in the transition period. Vet. Clin. North Am. Food Anim. Pract. 20:447-470.

Hammarstedt, A., C. X. Andersson, V. Rotter Sopasakis, and U. Smith. 2005. The effect of PPAR $\gamma$ ligands on the adipose tissue in insulin resistance. Prostaglandins Leukot. Essent. Fatty Acids 73:65-75.

Hawk, P. B., and O. Bergeim. 1926. Muscular tissue. Pages 559-574 in Practical Physiological Chemistry. 9th ed. Maple Press Co., York, PA.

Holtenius, K., S. Agenas, C. Delavaud, and Y. Chilliard. 2003. Effects of feeding intensity during the dry period. 2. Metabolic and hormonal responses. J. Dairy Sci. 86:883-891.

Houseknecht, K. L., B. M. Cole, and P. J. Steele. 2002. Peroxisome proliferator-activated receptor gamma (PPARgamma) and its ligands: A review. Domest. Anim. Endocrinol. 22:1-23.

Ide, T., T. Nakazawa, T. Mochizuki, and K. Murakami. 2000. Tissuespecific actions of antidiabetic thiazolidinediones on the reduced fatty acid oxidation in skeletal muscle and liver of Zucker diabetic fatty rats. Metabolism 49:521-525.

Kushibiki, S., K. Hodate, H. Shingu, Y. Ueda, M. Shinoda, Y. Mori, T. Itoh, and Y. Yokomizo. 2001. Insulin resistance induced in dairy steers by tumor necrosis factor alpha is partially reversed by 2,4-thiazolidinedione. Domest. Anim. Endocrinol. 21:25-37.
Larsen, P. J., P. B. Jensen, R. V. Sørensen, L. K. Larsen, N. Vrang, E. M. Wulff, and K. Wassermann. 2003. Differential influences of peroxisome proliferator-activated receptors $\delta$ and $\alpha$ on food intake and energy homeostatis. Diabetes 52:2249-2259.

Licitra, G., T. M. Hernandez, and P. J. Van Soest. 1996. Standardization of procedures for nitrogen fractionation of ruminant feeds. Anim. Feed Sci. Technol. 57:347-358.

McCutcheon, S. N., and D. E. Bauman. 1986. Effect of chronic growth hormone treatment on responses to epinephrine and thyrotropinreleasing hormone in lactating cows. J. Dairy Sci. 69:44-51.

National Research Council. 2001. Nutrient Requirements of Dairy Cattle. 7th rev. ed. National Academy Press, Washington, DC.

Overton, T. R., and M. R. Waldron. 2004. Nutritional management of transition dairy cows: Strategies to optimize metabolic health. J. Dairy Sci. 87(E Suppl.):E105-E119.

Rabelo, E., R. L. Rezende, S. J. Bertics, and R. R. Grummer. 2005. Effects of pre- and postfresh transition diets varying in dietary energy density on metabolic status of periparturient dairy cows. J. Dairy Sci. 88:4375-4383.

SAS Institute. 2001. SAS User's Guide. Statistics. Version 8 ed. SAS Inst. Inc., Cary, NC.

Sechen, S. J., S. N. McCutcheon, and D. E. Bauman. 1989. Response to metabolic challenges in early lactation dairy cows during treatment with bovine somatotropin. Domest. Anim. Endocrinol. $6: 141-154$.

Sevillano, J., I. C. Lopez-Perez, E. Herrera, M. Del Pilar Ramos, and C. Bocos. 2005. Englitazone administration to late pregnant rats produces delayed body growth and insulin resistance in their fetuses and neonates. Biochem. J. 389:913-918.

Sirois, P. K., M. J. Reuter, C. M. Laughlin, and P. J. Lockwood. 1994 A method for determining macro and micro elements in forages and feeds by inductively coupled plasma atomic emission spectrometry. Spectroscopist 3:6-9.

Smith, K. L. 2004. Effects of prepartum carbohydrate source and chromium supplementation in dairy cows during the periparturient period. MS Thesis. Cornell Univ., Ithaca, NY.

Smith, K. L., A. K. Rauf, B. C. Benefield, A. W. Bell, and T. R. Overton. 2006. Responses of tissues to insulin as affected by homeorhetic state in dairy cattle. J. Dairy Sci. 89(Suppl. 1):352. (Abstr.)

Sundvold, H., A. Brzozowska, and S. Lien. 1997. Characterisation of bovine peroxisome proliferator-activated receptors gamma 1 and gamma 2: Genetic mapping and differential expression of the two isoforms. Biochem. Biophys. Res. Commun. 239:857-861.

Van Soest, P. J., J. B. Robertson, and B. A. Lewis. 1991. Methods for dietary fiber, neutral detergent fiber, and nonstarch polysaccharides in relation to animal nutrition. J. Dairy Sci. 74:35833597.

Wildman, E. E., G. M. Jones, P. E. Wagner, R. L. Bowman, H. F. Trout, and T. N. Lesch. 1982. A dairy cow body condition scoring system and its relationship to selected production variables in high producing Holstein dairy cattle. J. Dairy Sci. 65:495-501. 